\title{
EXTRACTS OF FIVE CLADONIA LICHENS AS SOURCES OF BIOLOGICALLY ACTIVE COMPOUNDS
}

\author{
MARIJANA KOSANIĆ ${ }^{1} *$, SVETLANA RISTIĆ ${ }^{1}$, TATJANA STANOJKOVIĆ ${ }^{2}$, NEDELJKO \\ MANOJLOVIĆ $^{3}$, BRANISLAV RANKOVIĆ ${ }^{1}$ \\ ${ }^{I}$ Department of Biology, Faculty of Science, University of Kragujevac, 34000 Kragujevac, Serbia \\ ${ }^{2}$ Institute of Oncology and Radiology of Serbia, 11000 Belgrade, Serbia \\ ${ }^{3}$ Department of Pharmacy, Faculty of Medicinal Sciences, University of Kragujevac, 34000 Kragujevac, Serbia
}

*corresponding author: marijanakosanic@yahoo.com

Manuscript received: January 2018

\begin{abstract}
Five lichen species of Cladonia genus (C. fimbriata, C. furcata, C. subulata, C. foliacea and C. rangiferina) were examined. We described the chemical composition of the acetone extracts of the mentioned lichens and the antioxidant, antimicrobial and antitumor activities of their extracts. The phytochemical analysis was determined by HPLC-UV method. The depside (atranorin), depsidones (hypoprotocetraric acid and fumarprotocetraric acid) and dibenzofurane (usnic acid) were identified from these lichens. Antioxidant activity was evaluated by measuring the scavenging capacity of tested samples on 2,2diphenyl-1-picrylhydrazyl (DPPH) radicals, reducing power of samples and determination of total phenolic and flavonoid compounds in extracts. As a result of the antioxidant activity $C$. furcata showed the largest effect. The minimum inhibitory concentration (MIC) against five bacterial and 10 fungi was established. The extract of lichen $C$. fimbriata showed the strongest antibacterial activity (MIC values ranging from 0.625 to $20 \mathrm{mg} / \mathrm{mL}$ ) while, extract of the lichen C. subulata showed the strongest antifungal activity (MIC values were $0.625-20 \mathrm{mg} / \mathrm{mL})$. Cytotoxic activity was tested using 3-(4,5dimethylthiazol-2-yl)-2,5-diphenyltetrazolium bromide (MTT) method and all samples were found to be strong anticancer activity toward used cell lines with $\mathrm{IC}_{50}$ values ranging from 11.69 to $140.13 \mu \mathrm{g} / \mathrm{mL}$.
\end{abstract}

\section{Rezumat}

Au fost examinate cinci specii de lichen din genul Cladonia (C. fimbriata, C. furcata, C. subulata, C. foliacea și C. rangiferina). A fost descrisă compoziția chimică a extractelor în acetonă și activitatea antioxidantă, antimicrobiană şi antitumorală. Analiza fitochimică a fost determinată printr-o metodă HPLC-UV. Au fost identificate depsidele (atranorina), depsidonele (acidul hipoprotocetraric și acidul fumarprotocetraric) și dibenzofuranul (acidul usnic). Activitatea antioxidantă a fost evaluată prin metoda cu 2,2-difenil-1-picrilhidrazil (DPPH). Ca urmare a activității antioxidante, specia C. furcata a arătat cel mai mare efect. A fost stabilită concentrația minimă inhibitorie (CMI) asupra a cinci specii bacteriene și a 10 specii de ciuperci. Extractul de lichen $C$. fimbriata a prezentat cea mai puternică activitate antibacteriană (valorile CMI fiind cuprinse între 0,625 și $20 \mathrm{mg} / \mathrm{mL}$ ), în timp ce extractul de lichen C. subulata a prezentat cea mai puternică activitate antifungică (valorile CMI au fost cuprinse între $0,625-20 \mathrm{mg} / \mathrm{mL}$ ). Activitatea citotoxică a fost testată folosind metoda bromurii de 3(4,5-dimetiltiazol-2-il) -2,5-difeniltetrazoliu (MTT) şi s-a constatat că toate probele au demonstrat o activitate antitumorală puternică față de liniile celulare testate cu valori ale IC50 variind între 11,69 - 140,13 $\mu \mathrm{g} / \mathrm{mL}$.

Keywords: antioxidant activity, antimicrobial activity, cytotoxic activity, HPLC, lichen extracts

\section{Introduction}

A host of health problems including cancer, Alzheimer's disease, atherosclerosis and some of the drug-induced toxicity could be prevented. Oxidative stress which is associated with these diseases, occurs as result of unbalanced ratio of the production of reactive species and antioxidant defence activity. Antioxidants possess the ability to protect the body from damage caused by oxidative stress [1]. Considering that synthetic antioxidants are often carcinogenic [2], today is a great demand for antioxidants of natural origin.

On the other side, pathogenic microorganisms are serious threats to human health due to the increasing resistance that infectious agents have developed against synthetic antibiotics. Due to these, and many other reasons, there is a need for identifying and application of new natural substitutes. Looking for these substances of natural origin, lichens are the subject of numerous studies.

Lichens produce a great variety of secondary metabolites. About 1050 lichen secondary metabolites have been identified and most of them are unique for lichens [3]. Lichens and their metabolites can be a new alternative way in treating many diseases including cancer. It has been reported that they exhibit antimicrobial, antioxidant, antiviral, anticancer, antigen- 
FARMACIA, 2018, Vol. 66, 4

toxic, anti-inflammatory, analgesic and antipyretic potentials [4].

The aim of this study is to present the results of the phytochemical analysis of acetone extracts of five Cladonia lichens and their antioxidant, antimicrobial and anticancer activities in order to find an easily accessible source of natural antioxidants, antibiotics and anticancer agents that could be used as a possible food supplement, in the pharmaceutical industry and in the treatment of various diseases.

\section{Materials and Methods}

Collection and identification of lichen samples Lichen material of five Cladonia species - C. fimbriata (L.) Fr., C. furcata (Huds.) Schrad., C. subulata (L.) Weber ex F.H. Wigg., C. foliacea (Huds.) Willd., and C. rangiferina (L.) Weber ex F.H. Wigg, were collected from Serbia, during May 2013. Identification was done using relevant key and monographs $[5,6]$. The demonstration samples are preserved in facilities of the Department of Biology and Ecology of Kragujevac, Faculty of Science. Specimen of each species has been retained in our laboratory for future reference. Preparation of the lichen extracts

Dry ground thalli of the lichens C. fimbriata, C. furcata, C. subulata, C. foliacea and C. rangiferina (100 g) were extracted using acetone in a Soxhlet extractor. The extracts were filtered and then concentrated under reduced pressure in a rotary evaporator. The dry extracts were stored at $18^{\circ} \mathrm{C}$ until they were used in the tests. The extracts were dissolved in 5\% dimethylsulphoxide (DMSO) for the experiments.

High performance liquid chromatography (HPLC) analysis

Dry lichen extracts were redissolved in $500 \mu \mathrm{L}$ of acetone and analysed on a 1200 Series HPLC (Agilent Technologies) instrument with $\mathrm{C} 18$ column (C18; $25 \mathrm{~cm} 4.6 \mathrm{~mm}, 10 \mathrm{~m})$. UV spectrophotometric detector was used with methanol-water-phosphoric acid (75: 25:0.9, v/v/v) as solvent. The flow rate was $1 \mathrm{~mL} / \mathrm{min}$. Deionized water used throughout the experiments was generated by a Milli-Q academic water purification system (Milford, MA, USA). Phosphoric acid was analytical-grade reagent. Methanol was of HPLC grade and was purchased from Merck (Darmstadt, Germany). The sample injection volume was $10 \mu \mathrm{L}$. The standards used were obtained from the following sources: atranorin $\left(t_{R}=10.76 \pm 0.10\right)$ was isolated from the acetone extract of lichen Hypogimnia physodes and usnic acid $\left(t_{R}=9.75 \pm 0.30\right)$ was isolated from Usnea barbata. Fumarprotocetraric acid was isolated from the Cladonia rangiferina and hypoprotocetraric acid from Ramalina tumidula. All isolated compounds were identified by its spectroscopic data [7].
Antioxidant activity

Antioxidant activity was evaluated by free radical scavenging and reducing power. The free radical scavenging activity of lichen extracts was measured by 1,1-diphenyl-2-picryl-hydrazil (DPPH) according to the Dorman et al method [8]. The Oyaizu method [9] was used to determine the reducing power.

The amount of total phenols in the lichen extracts was determined as a pyrocatechol equivalent using Folin-Ciocâlteu reagent according to the Slinkard and Singleton's method [10]. The Dowd method [11] was used for the quantification of total flavonoid in the extracts with rutin as a standard.

Antimicrobial activity

Antimicrobial activities were evaluated against 15 microorganisms, including five strains of bacteria: Bacillus cereus (ATCC 11778), B. subtilis (ATCC 6633), Staphylococcus aureus (ATCC 25923), E. coli (ATCC 25922), Proteus mirabilis (ATCC 12453) and 10 species of fungi: Aspergillus flavus (ATCC 9170), A. niger (ATCC 16888), Candida albicans (ATCC 10231), Mucor mucedo (ATCC 20094), Trichoderma viride (ATCC 13233), Cladosporium cladosporioides (ATCC 11275), Fusarium oxysporum (ATCC 62506), Alternaria alternata (ATCC 11680), Penicillium expansum (ATCC 20466), P. chrysogenum (ATCC 10106) obtained from the American Type Culture Collection (ATCC).

The bacteria isolates were picked from over-night cultures in Müller-Hinton agar and suspensions were prepared in sterile distilled water by adjusting the turbidity to match $0.5 \mathrm{McF}$ arland standards to approximately $10^{8} \mathrm{CFU} / \mathrm{mL}$. Fungal suspensions were prepared from 3- to 7-day-old cultures that grew on a potato dextrose agar except for C. albicans that was maintained on Sabourad dextrose (SD) agar. The spores were rinsed with sterile distilled water, used to determine turbidity spectrophotometrically at $530 \mathrm{~nm}$, and then further diluted to approximately $10^{6} \mathrm{CFU} / \mathrm{mL}$ according to the procedure recommended by NCCLS [12].

The 96-well micro-titre assay using resazurin as the indicator of cell growth [13] was employed for the determination of the minimum inhibitory concentration (MIC) of the active components. Starting solutions of tested compounds were obtained by dissolving it in $5 \%$ dimethylsulphoxide (DMSO). Two fold serial dilutions of components were made in a concentration range from 40 to $0.004 \mathrm{mg} / \mathrm{mL}$ in sterile 96 -well plates containing Mueller-Hinton broth for bacterial cultures and a SD broth for fungal cultures. Then, resazurin solution was added as an indicator to each well and finally, to each well fungal or bacterial suspension was added. The inoculated microtiter plates were incubated at $37^{\circ} \mathrm{C}$ for 24 hours for bacteria and at $27^{\circ} \mathrm{C}$ for $72 \mathrm{hrs}$ for fungi. The MIC was determined visually and defined as the lowest concentration of tested compounds that prevented resazurin colour 
change from blue to pink. Streptomycin and ketoconazole were used as positive controls while $5 \%$ DMSO was used as the negative control.

Cytotoxic activity

Human epithelial carcinoma Hela cells (ATCC CCL2), human lung carcinoma A549 cells (ATCC CCL185) and human colon carcinoma LS174 cells (ATCC CL-188), were obtained from American Type Culture Collection (Manassas, VA, USA). All cancer cell lines were cultured as a monolayer in the RPMI 1640 nutrient medium, with $10 \% \mathrm{FBS}$ (inactivated at $56^{\circ} \mathrm{C}$ ), $3 \mathrm{mM}$ of L-glutamine, and antibiotics, at $37^{\circ} \mathrm{C}$ in humidified air atmosphere with $5 \% \mathrm{CO}_{2}$.

In vitro assay for cytotoxic activity of investigated samples was performed when the cells reached 70 $80 \%$ of confluence. Stock solution of extracts and compounds was dissolved in corresponding medium to the required working concentrations. Neoplastic Hela cells (5000 cells per well), A549 cells (5000 cells per well) and LS174 cells (5000 cells per well) were seeded into 96-well microtiter plates, and $24 \mathrm{~h}$ later, after cell adherence, five different, double diluted concentrations of investigated extracts were added to the wells. Final concentrations of the extracts were $200,100,50,25$, and $12.5 \mu \mathrm{g} / \mathrm{mL}$ except for the control wells, where only nutrient medium was added. The cultures were incubated for the next $72 \mathrm{~h}$.

The effect on cancer cell survival was determined $72 \mathrm{~h}$ after the addition of extract, by the MTT test [14]. Briefly, $20 \mu \mathrm{L}$ of MTT solution ( $5 \mathrm{mg} / \mathrm{mL}$ PBS) was added to each well and incubated for a further $4 \mathrm{~h}$ at $37^{\circ} \mathrm{C}$ in $5 \% \mathrm{CO}_{2}$ and humidified air. Subsequently, $100 \mu \mathrm{L}$ of $10 \mathrm{~g} / \mathrm{L}$ SDS was added to solubilise the formazan crystals formed from MTT after the conversion by mitochondrial dehydrogenases of viable cells. Absorbencies proportional to the number of viable cells were measured using a microplate reader (Multiskan EX, Thermo Scientific, Finland) at $570 \mathrm{~nm}$. Each experiment was performed in triplicate and independently repeated at least four times. As a positive control was used cis-DDP.

Statistical analyses

All data were presented as means \pm standard deviations (mean \pm SD) of three parallel measurements. Statistical analyses were performed using Microsoft Excel and SPSS software package.

\section{Results and Discussion}

High performance liquid chromatography (HPLC) analysis was used for identification the most often present secondary metabolites in the lichen genus Cladonia (C. fimbriata, C. furcata, C. subulata, $C$. foliacea and $C$. rangiferina). The chromatograms for standards (hypoprotocetraric acid, fumarportocetraric acid, atranorin and usnic acid) and lichen acetone extracts eluted by HPLC are represented in Figure 1 and Figure 2. Identification of these compounds was achieved by comparison of their $t_{R}$ values with the standard substances previously isolated from lichens.

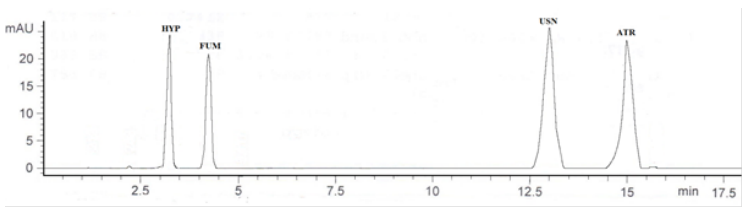

Figure 1.

HPLC chromatogram for selected lichen standards at 280 nm Peaks: HYP = hypoprotocetraric acid;

$\mathrm{FUM}=$ fumarprotocetraric acid; USN = usnic acid; $\mathrm{ATR}=$ atranorin

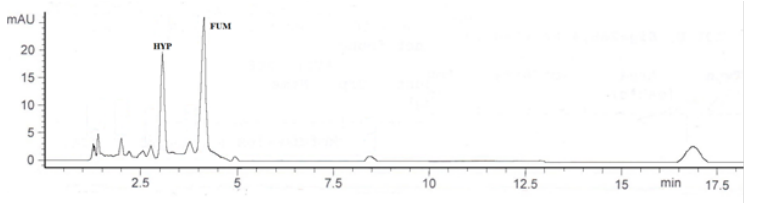

Cladonia subulata

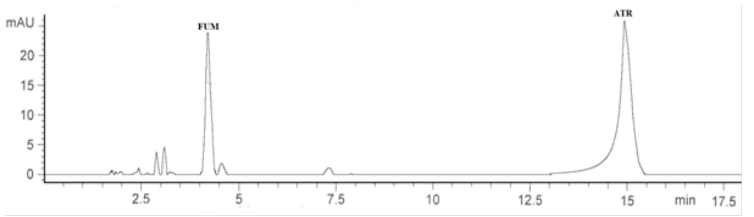

Cladonia rangiferina

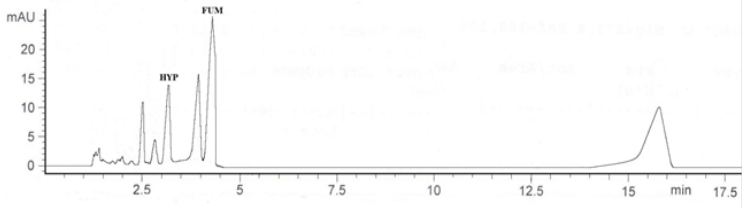

Cladonia furcata
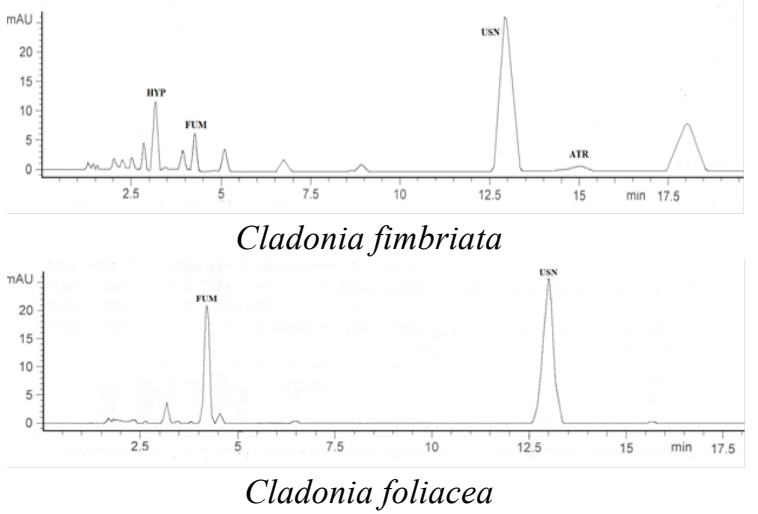

Figure 2.

The chromatograms of the acetone extracts of Cladonia fimbriata, Cladonia subulata, Cladonia furcata, Cladonia foliacea and Cladonia rangiferina at $280 \mathrm{~nm}$

By analysing the chemical composition of lichens $C$. subulata by HPLC-UV it was confirmed the presence of hypoprotocetraric acid (HYP) $\left(t_{R}=3.22 \pm 0.10\right)$ and fumarportocetraric acid (FUM) $\left(\mathrm{t}_{\mathrm{R}}=4.23 \pm 0.10\right)$. The same method was confirmed that the major metabolites of $C$. rangiferina are fumarportocetraric 
FARMACIA, 2018, Vol. 66, 4

acid and atranorin (ATR) $\left(t_{R}=15.06 \pm 0.10\right)$. Hypoprotocetraric acid and fumarprotocetraric acid were identified from the chromatogram of the extract $C$. furcata and fumarportocetraric acid and usnic acid (USN) $\left(t_{R}=13.10 \pm 0.10\right)$, from the extract of $C$. foliacea. The extract of $C$. fimbriata contains hypoprotocetraric acid, fumarprotocetraric acid, usnic acid (USN) and a small amount of the atranorin. Dominant peak in the chromatogram originates from dibenzofurane compound, usnic acid. Usnic acid was also has dominant peak in C. foliacea. For long years it was known that usnic acid have antimicrobial properties which can be correlated with our obtained results. As seen from the chromatogram, the acetone extracts of $C$. furcata, C. subulate and C. fimbriata contain hypoprotocetraric acid, while in the other tested extracts, this metabolite was not identified. On the other hand, fumarprotocetraric acid was identified in all investigated extracts. Atranorin belonging to the depsides while fumarprotocetraric acid and hypoprotocetraric acid are depsidones.

All tested extracts showed relatively high DPPH radical scavenging activity (Table I). $\mathrm{IC}_{50}$ values of lichen

extracts range from 183.41 to $312.56 \mu \mathrm{g} / \mathrm{mL}$. The acetone extract of $C$. furcata showed the highest DPPH radical scavenging activity.

Table I

DPPH radical scavenging activity of acetone extracts of examined lichens

\begin{tabular}{lc}
\hline Tested lichen species & $\begin{array}{c}\mathrm{DPPH} \text { radical scavenging } \\
\mathrm{IC}_{50}(\mu \mathrm{g} / \mathrm{mL})\end{array}$ \\
\hline Cladonia fimbriata & $213.48 \pm 3.35$ \\
Cladonia furcata & $183.41 \pm 2.12$ \\
Cladonia subulata & $312.56 \pm 4.09$ \\
Cladonia foliacea & $232.21 \pm 3.72$ \\
Cladonia rangiferina & $259.26 \pm 3.86$ \\
Ascorbic acid & $6.42 \pm 0.18$ \\
\hline alues are expressed as mean \pm SD of three parallel measurement
\end{tabular}

The results of the reducing power assay of lichen extracts are presented in Table II. Measured values of absorbances varied in range from 0.010 to 0.1178 . Higher absorbance indicates higher reducing power. The extract of $C$. furcata showed the highest reducing power, followed by $C$. foliacea, C. fimbriata, $C$. rangiferina and $C$. subulata.

Table II

Reducing power of acetone extracts of examined lichens

\begin{tabular}{lcccc}
\hline \multicolumn{1}{c}{ Lichen species } & \multicolumn{4}{c}{ Absorbance $(700 \mathrm{~nm})$} \\
\cline { 2 - 5 } & $1000 \mu \mathrm{g} / \mathrm{mL}$ & $500 \mu \mathrm{g} / \mathrm{mL}$ & $250 \mu \mathrm{g} / \mathrm{mL}$ & $125 \mu \mathrm{g} / \mathrm{mL}$ \\
\hline Cladonia fimbriata & $0.0543 \pm 0.005$ & $0.0507 \pm 0.003$ & $0.0403 \pm 0.006$ & $0.0284 \pm 0.002$ \\
Cladonia furcata & $0.1178 \pm 0.011$ & $0.0764 \pm 0.004$ & $0.0465 \pm 0.006$ & $0.0307 \pm 0.002$ \\
Cladonia subulata & $0.0347 \pm 0.002$ & $0.0273 \pm 0.002$ & $0.0258 \pm 0.004$ & $0.0130 \pm 0.001$ \\
Cladonia foliacea & $0.0763 \pm 0.004$ & $0.0394 \pm 0.002$ & $0.0321 \pm 0.005$ & $0.0239 \pm 0.002$ \\
Cladonia rangiferina & $0.0558 \pm 0.003$ & $0.0267 \pm 0.001$ & $0.0258 \pm 0.001$ & $0.0100 \pm 0.001$ \\
Ascorbic acid & $2.113 \pm 0.032$ & $1.654 \pm 0.021$ & $0.0957 \pm 0.008$ & $0.0478 \pm 0.004$ \\
\hline
\end{tabular}

Values are expressed as mean $\pm \mathrm{SD}$ of three parallel measurements

The total phenolic and flavonoid contents of the tested lichen extracts are presented in Table III. The total phenolics compounds was determined as the pyrocatechol equivalent using an equation obtained from a standard pyrocatechol graph $(\mathrm{y}=0.0057 \mathrm{x}$ total phenols [ $\mu \mathrm{g} \mathrm{PE} / \mathrm{mg}$ of dry extracts] $-0.1646, \mathrm{R}^{2}=$ 0.9934). The highest content of phenolic compounds was identified in the extract of $C$. furcata $39.86 \mu \mathrm{g}$ $\mathrm{PE} / \mathrm{mg}$.

Total phenolics and flavonoid content of acetone extracts of examined lichen species

Table III

\begin{tabular}{lcc}
\hline \multicolumn{1}{c}{ Lichen species } & Phenolics content $(\mu \mathrm{g}$ PE $/ \mathrm{mg}$ of extract $)$ & Flavonoid content $(\mu \mathrm{g} \mathrm{RU} / \mathrm{mg}$ of extract $)$ \\
\hline Cladonia fimbriata & $31.03 \pm 1.025$ & $1.89 \pm 0.505$ \\
Cladonia furcata & $39.86 \pm 1.121$ & $4.93 \pm 0.812$ \\
Cladonia subulata & $32.39 \pm 1.095$ & $5.20 \pm 0.933$ \\
Cladonia foliacea & $31.46 \pm 1.077$ & $4.21 \pm 0.879$ \\
Cladonia rangiferina & $31.74 \pm 1.018$ & $4.08 \pm 0.902$ \\
\hline lues are expressed as mean \pm SD of three parallel measurements; $\mathrm{PE}=$ pyrocatechol equivalents, $\mathrm{RU}=$ rutin equivalents
\end{tabular}

Values are expressed as mean \pm SD of three parallel measurements; $\mathrm{PE}=$ pyrocatechol equivalents, $\mathrm{RU}=$ rutin equivalents

The total amount of flavonoid compounds was determined as the rutin equivalent using an equation obtained from a standard rutin graph $(\mathrm{y}=0.0296 \mathrm{x}$ total flavonoid $[\mu \mathrm{g} \mathrm{RE} / \mathrm{mg}$ of dry extracts] +0.0204 , $\left.\mathrm{R}^{2}=0.9992\right)$. The acetone extract of $C$. subulata showed the highest content of flavonoid compounds (5.20 $\mu \mathrm{g} \mathrm{RE} / \mathrm{mg})$.
The results of the antimicrobial activity are summarized in Table IV. The higher antibacterial activity was in the acetone extracts of the lichen $C$. fimbriata, which had an inhibiting effect on all of the tested bacteria. Similar inhibitory activity but with a slightly higher concentrations showed an extract of $C$. furcata. The MIC for the acetone extracts of the lichen C. subulata, $C$. foliacea and $C$. rangiferina were within the range 
FARMACIA, 2018, Vol. 66, 4

$1.25-20 \mathrm{mg} / \mathrm{mL}$ in relation to the bacteria. These extracts did not show inhibitory activity against $E$. coli, which has proved to be the most resistant bacteria on all of the tested samples. Extract of lichen
C. subulata inhibited all tested fungi. Extracts of other lichen species did not exhibit inhibitory effect on the fungus A. flavus. The MIC fluctuated in the range from 1.25 to $20 \mathrm{mg} / \mathrm{mL}$.

Table IV

Minimum inhibitory concentration (MIC) of acetone extracts of examined lichen species

\begin{tabular}{|c|c|c|c|c|c|c|c|}
\hline $\begin{array}{ll}\text { Test microbes } & \text { Lichen species } \\
\end{array}$ & $\begin{array}{l}\text { Cladonia } \\
\text { fimbriata }\end{array}$ & $\begin{array}{l}\text { Cladonia } \\
\text { furcata }\end{array}$ & $\begin{array}{l}\text { Cladonia } \\
\text { subulata }\end{array}$ & $\begin{array}{l}\text { Cladonia } \\
\text { foliacea }\end{array}$ & $\begin{array}{c}\text { Cladonia } \\
\text { rangiferina }\end{array}$ & $\mathrm{S}$ & K \\
\hline S. aureus & $10^{*}$ & 10 & 20 & 20 & 20 & 0.031 & 1 \\
\hline B. subtilis & 1.25 & 5 & 5 & 10 & 2.5 & 0.016 & l \\
\hline B. cereus & 0.625 & 2.5 & 1.25 & 5 & 1.25 & 0.016 & l \\
\hline E. coli & 20 & 20 & / & / & l & 0.062 & l \\
\hline P. mirabilis & 5 & 2.5 & 10 & 10 & 10 & 0.062 & l \\
\hline M. mисеdo & 5 & 10 & 10 & 20 & 10 & I & 0.156 \\
\hline T. viride & 2.5 & 5 & 5 & 5 & 5 & l & 0.078 \\
\hline C. cladosporioides & 2.5 & 5 & 5 & 10 & 5 & l & 0.039 \\
\hline F. oxysporum & 5 & 10 & 5 & 10 & 10 & l & 0.078 \\
\hline A. alternata & 5 & 10 & 5 & 10 & 5 & / & 0.078 \\
\hline A.flavus & I & / & 20 & / & 1 & l & 0.312 \\
\hline A. niger & 10 & 10 & 10 & 10 & 20 & / & 0.078 \\
\hline C. albicans & 2.5 & 5 & 1.25 & 5 & 5 & l & 0.039 \\
\hline P. expansum & 10 & 20 & 10 & 20 & 20 & l & 0.156 \\
\hline P. chrysogenum & 10 & 10 & 5 & 20 & 10 & 1 & 0.078 \\
\hline
\end{tabular}

Values are given as milligram per milliliter. $\mathrm{S}=$ streptomycin, $\mathrm{K}=$ ketoconazole.

The result of cytotoxic activity of the studied lichens extracts, related to tested cell lines was shown in the Table V. The highest cytotoxic activity showed extract of $C$. foliacea against $\mathrm{A} 549\left(\mathrm{IC}_{50}=13.58 \pm 0.39\right)$ and $\mathrm{LS} 174\left(\mathrm{IC}_{50}=28.98 \pm 1.65\right)$ cell lines, while the highest cytotoxic activity against Hela cell lines exhibited extract of $C$. furcata $\left(\mathrm{IC}_{50}=11.69 \pm 0.45\right)$.

Growth inhibitory effects of acetone extracts of examined lichen species on Hela, A549 and LS174 cell lines

\section{Table V}

\begin{tabular}{cccc}
\hline Cell lines & Hela & $\mathrm{A} 549$ & $\mathrm{LS} 174$ \\
\hline Lichen species & \multicolumn{3}{c}{$\mathrm{IC}_{50}(\mu \mathrm{g} / \mathrm{mL})$} \\
\hline Cladonia fimbriata & $54.08 \pm 0.81$ & $70.45 \pm 1.84$ & $73.96 \pm 1.11$ \\
Cladonia furcata & $11.69 \pm 0.45$ & $63.67 \pm 0.58$ & $51.61 \pm 0.37$ \\
Cladonia subulata & $63.68 \pm 2.05$ & $47.33 \pm 2.71$ & $68.29 \pm 2.43$ \\
Cladonia foliacea & $20.27 \pm 1.25$ & $13.58 \pm 0.39$ & $28.98 \pm 1.65$ \\
Cladonia rangiferina & $49.83 \pm 2.16$ & $59.62 \pm 0.67$ & $140.13 \pm 2.61$ \\
cis-DDP & $0.83 \pm 0.19$ & $3.56 \pm 0.23$ & $2.58 \pm 0.16$ \\
\hline
\end{tabular}

$\mathrm{IC}_{50}$ values are expressed as the mean \pm SD determined from the results of MTT assay in three independent experiments

A great number of reports concerning the antimicrobial, antimicrobial and cytotoxic screening of lichens have appeared in the literature. According to published data, the lichens and their secondary metabolites appear to be good natural antioxidant, antimicrobial and anticancer agents.

In our study, the tested lichen extracts showed different levels of the antioxidant activity. Some metabolites of lichens including depsides, depsidones and dibenzofurans in their structure contain phenolic groups which are considered to be a key element for the antioxidative efficiency. Our tested lichens contain hypoprotocetraric acid, fumarprotocetraric acid, usnic acid and atranorin for which have been shown to exhibit powerful antioxidant activity. For example, Kosanić et al [15] investigated antioxidant activities of atranorin and fumarprotocetraric acid components from some Cladonia species. Antioxidant activities were evaluated by free radical scavenging, superoxide anion radical scavenging and reducing power. As a result of the study, isolated components had large antioxidant activity. Also, Melo et al [16] evaluated free radical scavenging and antioxidant activities of atranorin using various in vitro assays for scavenging activity against hydroxyl radicals, hydrogen peroxide, superoxide radicals and nitric oxide. Besides, the total reactive antioxidant potential and total antioxidant reactivity indexes and in vitro lipoperoxidation were also evaluated. They found that atranorin exerts differential effects towards reactive species production, enhancing hydrogen peroxide and nitric oxide production and acting as a superoxide scavenger; than activity towards hydroxyl radical production scavenging was observed. Also, total reactive antioxidant potential and total antioxidant reactivity analysis indicated that atranorin acts as a general antioxidant, although it demonstrated to enhance peroxyl radical-induced lipoperoxidation in vitro. Similarly, Manojlović et 
FARMACIA, 2018, Vol. 66, 4

al [17] investigated antioxidant activities for usnic acids from Parmelia caperata lichen. Antioxidant activities of this isolated metabolite were evaluated by free radical scavenging, superoxide anion radical scavenging and reducing power. As a result of the study, usnic acid had strong antioxidant activity in all used tests. In our study, among the tested lichens, C. fimbriata showed a high level of the activity towards the DPPH radicals and also high reducing power. The extract of $C$. fimbriata contains hypoprotocetraric acid, fumarprotocetraric acid, usnic acid (USN) and a small amount of the atranorin for which is a proven antioxidant activity, so that such activity was expected.

The tested lichen extracts also showed relatively strong antimicrobial activity. These results are in accordance with previous studies. Mitrović et al [18] studied antibacterial and antifungal activity of methanol extracts of five lichen species including $C$. foliacea and they found that $C$. foliacea manifested the strongest antimicrobial activity among tested lichens. Similarly, extracts of the lichens Cladonia furcata, Lecanora atra, and L. muralis were studied for their antimicrobial potential by Ranković et al [19]. The extract of C. furcata was the most active antimicrobial agent with very low MIC values. Relatively strong antimicrobial effects against numerous bacteria and fungi was also found for lichen components that constitute tested Cladonia species (usnic acid, atranorin and fumarprotocetraric acid), especially for usnic acid which was the strongest antibiotic with remarkably low MICs [20-22]. The strong antimicrobial activity of usnic acid is known for a long time. Antibiotic activity of usnic acid against Gram-positive bacteria was attributed to its protonophoric properties as an uncoupler of oxidative phosphorylation [23]. Maciag-Dorszynska et al [24] found that inhibition of RNA synthesis could be a general mechanism of antibacterial action of usnic acid, with additional, such as impairment of DNA replication in Bacillus subtilis and Staphylococcus aureus.

In these experiments, antibacterial effect was observed against the both Gram positive and Gram negative bacteria, but it should be noted that the Gram negative bacteria were more resilient. It has been generally reported that the Gram negative bacteria are more resistant than Gram positive. This resistance is likely due to the fact that Gram negative bacteria have a wall associated with an outer complex membrane, which slows down the passage of hydrophobic compounds. Lacking outer membrane, Gram positive bacteria are more susceptible to the antibiotic agents. Compared to the bacteria, fungi were more resistant due to the more complex structure of the cell wall [25-27].

In present research, the results indicate that studied extracts induced relatively strong cytotoxic activity, which was previously confirmed with numerous researches which are tested cytotoxic effect of some other Cladonia lichens and their constituents.

Bessadottir et al [28] emphasized that C. arbuscula induced the formation of autophagosomes in human cancer cells, but had minimal effects on normal human fibroblasts. Brisdelli et al [29] reported about anticarcinogenic activity of $C$. lepidophora which is manifested anti-proliferative effect against MCF-7 (breast adenocarcinoma), HeLa (cervix adenocarcinoma) and HCT-116 (colon carcinoma) cells. Bezivin et al [30] found that the (-)-enantiomer of usnic acid which is isolated from lichen $C$. convoluta induced apoptotic cell death in murine lymphocytic leukaemia cells and was moderately cytotoxic to murine Lewis lung carcinoma, human chronic myelogenous leukaemia, human brain metastasis of a prostate carcinoma, human breast adenocarcinoma and human glioblastoma. Usnic acid-treated cells showed reduced ATP levels and activation of AMP kinase as well as signs of cellular stress. Usnic acid is thus likely to trigger autophagosome formation both by energy depletion and stress conditions. Strong cytotoxic action of usnic acid $(25-100 \mu \mathrm{M})$ was demonstrated against several human cancer cell lines such as FemX (melanoma), LS174 (colon carcinoma) MCF-7 (breast adenocarcinoma), HeLa (cervix adenocarcinoma), HCT-116 (colon carcinoma) U937 (monocytic leukemia), HL-60 (monocytic leukemia), A2780 (ovarian carcinoma), SK-BR-3 (breast adenocarcinoma), HT-29 (colon adenocarcinoma), HCT-116 p53-/- (colon carcinoma p53-null subline) and Jurkat ( $\mathrm{T}$ cells lymphocyte leukaemia) [25, 29, 31, 32]. Also, fumarprotocetraric acid earlier isolated from $C$. rangiferina exhibited strong anticancer activity against the FemX and LS174 cell lines, consistent with the induction of apoptosis in a cell cycle-dependent manner [15].

\section{Conclusions}

Antioxidant, antimicrobial and antitumour activities of acetone extracts of the five Cladonia lichens are tested. The present study represents selected lichens as very interesting source of bioactive compounds which provide unlimited opportunities for new antioxidant, antimicrobial and anticancer agents. This study suggests that the tested lichens can be productively used in the food industry and pharmaceutical area because of its possible activities reported. Further, new chemical components are still being detected. More detailed in vitro as well as in vivo studies are necessary to establish the potential biological activity properties of lichen extracts and lichen compounds.

\section{Acknowledgement}

This work was financed in part by the Ministry of Science, Technology and Development of the Republic 
FARMACIA, 2018, Vol. 66, 4

of Serbia and was carried out within the framework of projects no. 173032, 175011 and 172015.

\section{References}

1. Souri E, Amin G, Farsam H, Jalalizadeh H, Barezi $\mathrm{S}$, Screening of thirteen medicinal plant extracts for antioxidant activity. Iran J Pharm Res., 2008; 7: 149-154.

2. Zhang XY, da Chen C, Xiu MH, The novel oxidative stress marker thioredoxin is increased in first-episode schizophrenic patients. Schizophr Res., 2009; 113: 151-157.

3. Shukla V, Joshi G, Rawat M, Lichens as a potential natural source of bioactive compounds: a review. Phytochem Rev., 2010; 9: 303-314.

4. Ranković B, Kosanić M, Lichens as a potential source of bioactive secondary metabolites. In: Ranković B, editor. Lichen secondary metabolites bioactive properties and pharmaceutical potential. Springer International Publishing Switzerland; 2015: 1-26.

5. Wirth V, Die Flechten Baden-Würtembergs, Verbreitungsatlas, 1\&2; Eugen Ulmer GmbH\&Co: Stuttgart, Germany. 1995.

6. Dobson FS, Lichens. An illustrated guide to the British and Irish species, sixth ed. Richmond Publishing Co. London. 2011.

7. Huneck S, Yoshimura I, Identification of lichen substances. Berlin Heidelberg: Springer-Verlag. 1996.

8. Dorman HJ, Bachmayer O, Kosar M, Hiltunen R, Antioxidant properties of aqueous extracts from selected Lamiaceae species grown in Turkey. J Agric Food Chem., 2004; 52: 762-770.

9. Oyaizu M, Studies on products of browning reaction prepared from glucoseamine. Jpn J Nutr., 1986; 44: 307-314.

10. Slinkard K, Singleton VL, Total phenolic analyses: automation and comparison with manual method. Am J Enol Viticult., 1997; 28: 49-55.

11. Meda A, Lamien CE, Romito M, Millogo J, Nacoulma OG, Determination of the total phenolic, flavonoid and proline contents in Burkina Fasan honey, as well as their radical scavenging activity. Food Chem., 2005; 91: 571-577.

12. NCCLS (National Committee for Clinical Laboratory Standards). Reference method for broth dilution antifungal susceptibility testing of conidium-forming filamentous fungi: Proposed standard M38-p. Wayne, PA, USA: NCCLS. 1998.

13. Sarker SD, Nahar L, Kumarasamy Y, Microtitre platebased antibacterial assay incorporating resazurin as an indicator of cell growth, and its application in the in vitro antibacterial screening of phytochemicals. Methods, 2007; 42: 321-324.

14. Mosmann T, Rapid colorimetric assay for cellular growth and survival: application to proliferation and cytotoxicity assays. J Immunol Methods, 1983; 65: 55-63.

15. Kosanić M, Ranković B, Stanojković T, Rančić A, Manojlović N, Cladonia lichens and their major metabolites as possible natural antioxidant, antimicrobial and anticancer agents. LWT Food Sci Technol., 2014; 59: 518-525.
16. Melo MG, dos Santos JP, Serafini MR, Caregnato FF, Pasquali MA, Rabelo TK, da Rocha RF, Quintans L Jr, Araújo AA, da Silva FA, Moreira JC, Gelain DP, Redox properties and cytoprotective actions of atranorin, a lichen secondary metabolite. Toxicol In Vitro, 2011; 25: 462-468.

17. Manojlović N, Ranković B, Kosanić M, Vasiljević P, Stanojković T, Chemical composition of three Parmelia lichens and antioxidant, antimicrobial and cytotoxic activities of some their major metabolites. Phytomed., 2012; 19: 1166-1172.

18. Mitrović T, Stamenković S, Cvetković V, Tošić S, Stanković M, Radojević I, Stefanović O, Comić L, Dačić D, Curčić M, Marković S, Antioxidant, antimicrobial and antiproliferative of five lichen species. Int J Mol Sci., 2011; 12: 5428-5448.

19. Ranković B, Kosanić M, Stanojković T, Antioxidant, antimicrobial and anticancer activity of the lichens Cladonia furcata, Lecanora atra and Lecanora muralis. BMC Complem Altern Med., 2011; 11: 1-8.

20. Ranković B, Mišić M, The antimicrobial activity of the lichen substances of the lichens Cladonia furcata, Ochrolechia androgyna, Parmelia caperata and Parmelia conspersa. Biotechnol Biotechnol Equip., 2008; 22: 1013-1016.

21. Yilmaz M, Turk AO, Tay T, Kivanc M, The antimicrobial activity of extracts of the lichen Cladonia foliacea and its (-)-usnic acid, atranorin, and fumarprotocetraric acid constituents. Z Naturforsch C., 2004; 59: 249-254.

22. Verma N, Behera BC, Parizadeh H, Sharma BO, Bactericidal activity of some lichen secondary compounds of Cladonia ochrochlora, Parmotrema nilgherrensis and Parmotrema sanctiangelii. Int. $J$ Drug Dev Res., 2011; 3: 222-232.

23. Abo-Khatwa AN, al-Robai AA, al-Jawhari DA, Lichen acids as uncouplers of oxidative phosphorylation of mouse-liver mitochondria. Nat Toxins, 1996; 4: 96-102.

24. Maciag-Dorszynska M, Wegrzyn G, Guzow-Krzeminska $\mathrm{B}$, Antibacterial activity of lichen secondary metabolite usnic acid is primarily caused by inhibition of RNA and DNA synthesis. FEMS Microbiol Lett., 2014; 353: 57-62.

25. Ranković B, Kosanić M, Stanojković T, Vasiljević P, Manojlović N, Biological activities of Toninia candida and Usnea barbata Together with their norstictic acid and usnic acid constituents. Int J Mol Sci., 2012; 13: 14707-14722.

26. Kosanić M, Ranković B, Rančić A, Stanojković T, Evaluation of metal concentration and antioxidant, antimicrobial, and anticancer potentials of two edible mushrooms Lactarius deliciosus and Macrolepiota procera. J Food Drug Anal., 2016; 24: 477-484.

27. Ristić S, Ranković B, Kosanić M, Stanojković T, Stamenković S, Vasiljević P, Manojlović I, Manojlović $\mathrm{N}$, Phytochemical study and antioxidant, antimicrobial and anticancer activities of Melanelia subaurifera and Melanelia fuliginosa lichens. J Food Sci Tech Mys., 2016; 53: 2804-2816.

28. Bessadottir M, Egilsson M, Einarsdottir E, Magnusdottir $\mathrm{IH}$, Ogmundsdottir MH, Omarsdottir S, Ogmundsdottir HM, Proton-shuttling lichen compound usnic acid affects mitochondrial and lysosomal function in cancer cells. PLoS One., 2012; 7(12): 1-7. 
29. Brisdelli F, Perilli M, Sellitri D, Piovano M, Garbarino JA, Nicoletti M, Bozzi A, Amicosante G, Celenza G, Cytotoxic activity and antioxidant capacity of purified lichen metabolites: An in vitro study. Phytother Res., 2013; 27: 431-437.

30. Bezivin C, Tomasi S, Rouaud I, Delcros JG, Boustie J, Cytotoxic activity of compounds from the lichen: Cladonia convoluta. Planta Med., 2004; 70: 874-877.

31. Marante FJT, Castellano AG, Rosas FE, Aguiar JQ, Barrera JJB, Identification and quantitation of allelo- chemicals from the lichen Lethariella canariensis: Phytotoxicity and antioxidative activity. Chem Ecol., 2003; 29: 2049-2071.

32. Bačkorová M, Bačkor M, Mikeš J, Jendželovský R, Fedoročko $\mathrm{P}$, Variable responses of different human cancer cells to the lichen compounds parietin, atranorin, usnic acid and gyrophoric acid. Toxicol In Vitro, 2011; 25: 37-44. 